\title{
Substantiation of the Approach to Selecting the Depreciation Method for Property, Plant, and Equipment
}

\author{
Tetiana Dolishnia* \\ Accountig and Taxation Department \\ Ivano-Frankivsk National Technical \\ University of Oil and Gas \\ Ivano-Frankivsk, Ukraine \\ tanjadolishnja@gmail.com; \\ orcid.org/0000-0003-0972-4219
}

\author{
Iryna Medvid \\ Accountig and Taxation Department \\ Ivano-Frankivsk National Technical \\ University of Oil and Gas \\ Ivano-Frankivsk, Ukraine \\ medvid@ua.fm; \\ orcid.org/0000-0003-1476-2316 \\ Yuliia Stakhmych \\ Department of Philology \\ and Translation Studies \\ Ivano-Frankivsk National Technical \\ University of Oil and Gas \\ Ivano-Frankivsk, Ukraine \\ julia.stakhmych@gmail.com; \\ orcid.org/0000-0003-4661-8220
}

\author{
Olga Stepanyuk \\ Accountig and Taxation Department \\ Ivano-Frankivsk National Technical \\ University of Oil and Gas \\ Ivano-Frankivsk, Ukraine \\ stepoljas@gmail.com; \\ orcid.org/0000-0001-7324-1233
}

\begin{abstract}
The purpose of the article is to substantiate the approach to selecting the depreciation method in oil and gas companies.

To achieve this purpose, the following research methods were used: observation, comparison, integrated study of business transactions - to collect factual information on the use of depreciation methods in oil and gas companies; abstraction, analysis - to substantiate the approach to selecting the depreciation method for property, plant, and equipment; graphical method - for the visual presentation of research material.
\end{abstract}

The scientific novelty of the study is that the authors have substantiated the approach to selecting the depreciation method for property, plant, and equipment in oil and gas companies. In order to optimally select the depreciation method the authors have proposed to develop a testing system with the help of the automated accounting system. It will test property, plant, and equipment within different groups, in particular in terms of the anticipated revenues, nature of assets use, etc.

This will help to improve the qualitative characteristics of financial statements in terms of the reliability of information about property, plant, and equipment.

Keywords-property, plant, and equipment, depreciation methods, financial statements, oil and gas companies.

\section{INTRODUCTION}

Property, plant, and equipment play an important role in business activities of oil and gas companies. For example, in the property of Joint Stock Company "National Joint Stock Company Naftogaz of Ukraine" the proportion of property, plant, and equipment was $78.8 \%(551,661 \mathrm{UAH})$ in 2016 ,
$68 \%(491,482 \mathrm{UAH})$ in $2017,71.9 \%(434,370 \mathrm{UAH})$ in 2018 [1].

The gradual depreciation of property, plant, and equipment begins when they are available for use. The amount of lost value is by with the amount of depreciation charge.

The depreciation methods for property, plant, and equipment are specified in the accounting policy and selected by the company, which takes into account the expected consumption pattern of the future economic benefits, embodied in the asset.

Thus, the oil and gas companies with a complex structure of property, plant, and equipment often wonder which of the depreciation methods should be applied to property, plant, and equipment. The depreciation charges are added to the period costs or the cost of produced goods (works, services), then they change the value of the financial result, or the original cost of the created items of property, plant, and equipment. Eventually they affect the financial statements of the company. Since accounting is aimed at providing accurate and unbiased information to internal and external users, it is important to optimally select the depreciation method.

The studies on improving the qualitative characteristics of financial statements, including the reliability of information about property, plant, and equipment, were conducted by many Ukrainian and foreign scientists. In particular, I. M. Sacer [2], S. S. Malis [2], I. Pavic [2], G. Njowa [2], C. Musingwini [3], G. Njowa [3], M. P. Bauman [4], Z. Zadorozhnii [5, 8], S. Kafka [5], M. I. Bondar [6], S. A. Kuznetsova [7], A. A. Kuznetsov [7], L. H. Semehen [8], L. T. Bohutska [8]. However, despite significant scientific developments, a whole range of issues remain controversial nowadays. One of them is the 
problem of optimal selection of depreciation method for property, plant, and equipment.

The purpose of this article is to substantiate the approach to selecting the depreciation method in oil and gas companies.

The contributions of our work are as follows:

1. In order to help optimally select the depreciation method the testing system has been proposed to be developed with the help of the automated accounting system. It will test property, plant, and equipment within different groups, in particular in terms of the anticipated revenues, nature of assets use, etc.

2. The use of recommendations on the approach to selecting the depreciation method for property, plant, and equipment in the oil and gas companies will help to improve the qualitative characteristics of financial statements in terms of the reliability of information about property, plant, and equipment.

To achieve the set purpose, the following research methods were used: observation, comparison, integrated study of business transactions - to collect factual information on the use of depreciation methods in oil and gas companies; abstraction, analysis - to substantiate the approach to selecting the depreciation method for property, plant, and equipment; graphical method - for the visual presentation of research material.

\section{RESEARCH RESULTS}

Nowadays Ukrainian standards recommend using the following depreciation methods for property, plant, and equipment (except other non-current tangible assets): straight-line method, diminishing balance method, accelerated diminishing balance method, cumulative and production methods. For other non-current tangible assets (except for non-current tangible assets of low cost) only straight-line and production methods should be used.

The non-current tangible assets of low cost can be fully depreciated in the first month of use or can be depreciated at $50 \%$ in the first month of use and 50\% in the month when the assets are retired from active use.

However, changes to the current legislation [9] make it necessary for almost all oil and gas companies to prepare financial statements in accordance with International Financial Reporting Standards (IFRS). This necessitates an in-depth study of the provisions of international standards, in particular those relating to depreciation.

The analysis results of the use of depreciation methods (Table 1) show that the oil and gas companies mainly use the straight-line method.

Compared to the Ukrainian Accounting Standard (UAS) 7 "Property, Plant, and Equipment" [18], the International Accounting Standard (IAS) 16 "Property, Plant, and Equipment" [17] proposes three depreciation methods: straight-line method; diminishing balance method; units of production method.

The depreciation methods have the following results:
TABLE I. DEPRECIATION METHODS USED IN OIL AND GAS COMPANIES

\begin{tabular}{|c|c|c|}
\hline List of companies & $\begin{array}{c}\text { Regulatory } \\
\text { documents } \\
\text { certifying the } \\
\text { selection of } \\
\text { depreciation } \\
\text { method for } \\
\text { property, plant, } \\
\text { and equipment }\end{array}$ & $\begin{array}{c}\text { List of depreciation } \\
\text { methods }\end{array}$ \\
\hline $\begin{array}{l}\text { JSC "NJSC Naftogaz of } \\
\text { Ukraine" }\end{array}$ & $\begin{array}{l}\text { Paragraph } 25 \text { of } \\
\text { the Notes to } \\
\text { Separate Financial } \\
\text { Statement of } \\
\begin{array}{l}\text { December } 31, \\
2018\end{array}\end{array}$ & $\begin{array}{l}\text { The depreciation of } \\
\text { property, plant, and } \\
\text { equipment is } \\
\text { calculated on a } \\
\text { straight-line basis } \\
\text { over their expected } \\
\text { useful lives [1]. }\end{array}$ \\
\hline $\begin{array}{l}\text { JSC } \\
\text { "Ukrgasvydobuvannya" }\end{array}$ & $\begin{array}{l}\text { Paragraph } 28 \text { of } \\
\text { the Notes to } \\
\text { Financial } \\
\text { Statement, } 2018\end{array}$ & $\begin{array}{l}\text { Straight-line method } \\
\text { is used for } \\
\text { depreciation, except } \\
\text { for the depreciation } \\
\text { of wells, specialized } \\
\text { drilling tools and } \\
\text { property, plant, and } \\
\text { equipment involved } \\
\text { in the work at wells. } \\
\text { The depreciation on } \\
\text { these assets is } \\
\text { calculated by the } \\
\text { units of production } \\
\text { method [10]. }\end{array}$ \\
\hline PJSC "Ukrnafta" & $\begin{array}{l}\text { Paragraph } 3 \text { of the } \\
\text { Notes to Separate } \\
\text { Financial } \\
\text { Statement, } 2018\end{array}$ & $\begin{array}{l}\text { Straight-line method } \\
\text { is used (with the } \\
\text { exception of oil and } \\
\text { gas assets). Oil and } \\
\text { gas assets are } \\
\text { depreciated by the } \\
\text { production method } \\
\text { (units of production } \\
\text { depreciation method) } \\
\text { [11]. }\end{array}$ \\
\hline JSC “Ukrtransgaz" & $\begin{array}{l}\text { Paragraph } 22 \text { of } \\
\text { the Notes to } \\
\text { Separate Financial } \\
\text { Statement, } 2018\end{array}$ & $\begin{array}{l}\text { The depreciation of } \\
\text { property, plant, and } \\
\text { equipment is } \\
\text { calculated on a } \\
\text { straight-line basis } \\
\text { over their expected } \\
\text { useful lives [12]. }\end{array}$ \\
\hline PJSC "Ukrtransnafta" & $\begin{array}{l}\text { Paragraph } 22 \text { of } \\
\text { the Notes to } \\
\text { Financial } \\
\text { Statement, } 2018\end{array}$ & $\begin{array}{l}\text { The depreciation of } \\
\text { property, plant, and } \\
\text { equipment is } \\
\text { calculated on a } \\
\text { straight-line basis } \\
\text { over their expected } \\
\text { useful lives [13]. }\end{array}$ \\
\hline PJSC "Ukrtatnafta" & $\begin{array}{l}\text { Paragraph } 4 \text { of the } \\
\text { Notes to Financial } \\
\text { Statement, } 2017\end{array}$ & $\begin{array}{l}\text { Straight-line method } \\
{[14]}\end{array}$ \\
\hline PJSC "Donetskoblgaz" & $\begin{array}{l}\text { Paragraph } 2 \text { of the } \\
\text { Notes to Financial } \\
\text { Statement, } 2018\end{array}$ & $\begin{array}{l}\text { Straight-line method } \\
{[15]}\end{array}$ \\
\hline PJSC “Kyivoblgaz" & $\begin{array}{l}\text { Paragraph } 2 \text { of the } \\
\text { Notes to Financial } \\
\text { Statement, } 2018\end{array}$ & $\begin{array}{l}\text { Straight-line method } \\
{[16]}\end{array}$ \\
\hline
\end{tabular}

- straight-line method - constant charge over the useful life of assets;

- diminishing balance method - decreasing charge over the useful life of assets;

- units of production method - charge based on the expected use or output of the asset [17]. 
The proposed methods are not "ideal" and are rather relative. They have their advantages and disadvantages, which are represented in Table 2.

TABLE II. ADVANTAGES AND DISADVANTAGES OF DEPRECIATION METHODS

\begin{tabular}{|c|c|c|c|}
\hline $\begin{array}{l}\text { List of } \\
\text { depreciation } \\
\text { methods for } \\
\text { property, } \\
\text { plant, and } \\
\text { equipment }\end{array}$ & $\begin{array}{l}\text { Deprecia } \\
\text { tion } \\
\text { formula }\end{array}$ & Advantages & Disadvantages \\
\hline $\begin{array}{l}\text { Straight-line } \\
\text { method }\end{array}$ & $\begin{array}{l}\text { (Original } \\
\text { (Revalue } \\
\text { d) Cost - } \\
\text { Residual } \\
\text { Value) / } \\
\text { Useful } \\
\text { Life }\end{array}$ & $\begin{array}{l}\text { Depreciation } \\
\text { charges are } \\
\text { the same each } \\
\text { year over the } \\
\text { service life of } \\
\text { the asset. }\end{array}$ & $\begin{array}{l}\text { Does not take into } \\
\text { account } \\
\text { obsolescence. Does not } \\
\text { take into account the } \\
\text { use (operation) rate. }\end{array}$ \\
\hline $\begin{array}{l}\text { Diminishing } \\
\text { balance } \\
\text { method }\end{array}$ & $\begin{array}{l}\text { Rate of } \\
\text { Depreciat } \\
\text { ion X } \\
\text { Carrying } \\
\text { Amount / } \\
\text { Useful } \\
\text { Life }\end{array}$ & $\begin{array}{l}\text { Takes into } \\
\text { account the } \\
\text { obsolescence. }\end{array}$ & $\begin{array}{l}\text { The depreciation } \\
\text { charge is not affected } \\
\text { by the residual value. } \\
\text { Does not reflect the } \\
\text { actual wear rate. }\end{array}$ \\
\hline $\begin{array}{c}\text { Units of } \\
\text { production } \\
\text { (production) } \\
\text { method }\end{array}$ & $\begin{array}{l}\text { (Original } \\
\text { Cost - } \\
\text { Residual } \\
\text { value) } \mathrm{x} \\
\text { (Number } \\
\text { of units } \\
\text { produced } \\
\text { / Life in } \\
\text { number } \\
\text { of units) }\end{array}$ & $\begin{array}{l}\text { Reflects the } \\
\text { actual wear } \\
\text { rate. }\end{array}$ & $\begin{array}{l}\text { Does not take into } \\
\text { account the } \\
\text { obsolescence. The } \\
\text { necessity of accounting } \\
\text { the actual quantity of } \\
\text { products, works, } \\
\text { services. There is often } \\
\text { the absence or } \\
\text { impossibility of } \\
\text { defining the planned } \\
\text { quantity of products, } \\
\text { works, and services. } \\
\text { Does not take into } \\
\text { account the useful life. }\end{array}$ \\
\hline
\end{tabular}

Table 2 shows that the calculation of depreciation is based on three main components: original cost, residual value, and useful life. The original cost is formed by the company depending on the method of obtaining property, plant, and equipment. The International Accounting Standard IAS 16 "Property, Plant, and Equipment" defines the residual value of an asset as an estimated amount that an entity could currently receive from asset disposal after deducting the estimated disposal costs, if the asset were obsolete and in condition, expected at the end of its useful life [17]. That is, the company estimates the residual value as an amount it could currently obtain (according to the preliminary estimate) from disposal of assets and in the conditions expected at the end of their useful life.

It should be noted that international standards provide a clearer definition of residual value than Ukrainian standards, in particular due to the emphasis on time aspect.

The selection of depreciation method correlates with the useful life - a period during which an asset is expected to be available for use [17]. This is true of the straight-line and diminishing balance methods, but not of the units of production depreciation method. Thus, the useful life is defined based on the expected usefulness of the asset to the company.

The future economic benefits embodied in the asset are consumed by the company primarily through its use.
However, there are other factors that cause the diminution of the expected economic benefits of the asset and should be taken into account when defining the useful life:

- the expected usage of the asset with account of its capacity or physical output;

- the expected physical wear and tear and obsolescence, which depend on such operational factors as the number of shifts during which the asset is to be used, repair and maintenance programs, etc.;

- the expected technical wear and tear depending on the current trends in production;

- legal or other limits on the useful life of the assets and other factors [17].

All of the above factors should be taken into account when selecting the depreciation method.

The results of applying the straight-line, diminishing balance and units of production depreciation methods (Fig. 1,2) show that the selection of different methods does not affect the total depreciation charge, but only the depreciation charge in each accounting period. The calculations were based on the following input data on property, plant, and equipment: original cost - 90,000 UAH; residual value - 10,000 UAH; useful life - 5 (8) years; planned production quantity for the entire period of operation - 200,000 UAH; actual production quantity: 1st year - 35,000 UAH; 2nd year - 44,400 UAH; 3rd year $32,000 \mathrm{UAH} ;$ 4th year - 27,000 UAH; 5th year $21,000 \mathrm{UAH} ; 6$ th year - 18,000 UAH; 7th year $13,100 \mathrm{UAH}$; 8th year $-9,500 \mathrm{UAH}$.

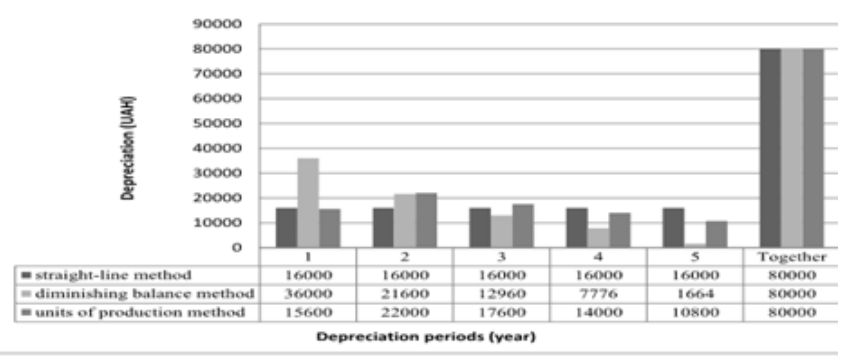

Fig. 1. Depreciation charges calculated by different methods with the useful life of 5 years

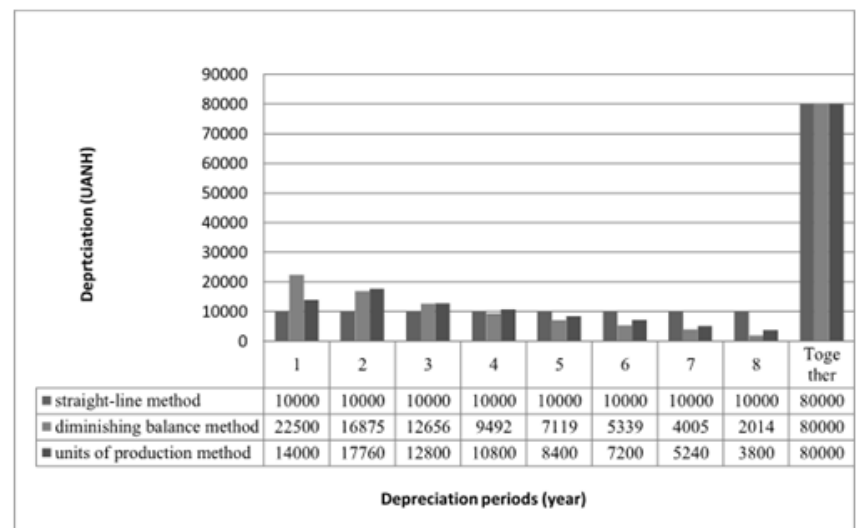

Fig. 2. Depreciation charges calculated by different methods with the useful life of 8 years 
These charts prove the impact of useful life (straight-line and diminishing balance depreciation methods) on the amount of depreciation charges, provided that other parameters do not change.

Thus, the company selects the method that most closely reflects the expected consumption pattern of the future economic benefits embodied in the asset.

\section{CONCLUSIONS}

1. Selecting the right depreciation method will improve the quality of financial statements, as the balance between revenues and expenses is the fundamental principle of accounting.

2. One of the main elements influencing the choice of depreciation method is the useful life. Therefore, when selecting the depreciation method it is necessary to take into account all factors that affect the useful life, namely the expected usage of the asset with account of its capacity or physical output; the expected physical wear and tear and obsolescence depending on such operational factors as the number of shifts during which the asset is to be used, repair and maintenance programs, etc.; the expected technical wear and tear depending on the current trends in production; legal or other limits on the useful life of the assets and other factors.

3. Oil and gas companies mostly use the straight-line method to calculate the depreciation of property, plant, and equipment.

In order to optimally select the depreciation method, it was proposed to test property, plant, and equipment for the expected revenues from the use of property, plant, and equipment, nature of assets use, etc.

If property, plant, and equipment generate the same income throughout their useful life, then it is reasonable to select the straight-line method, and if the income from the use of property, plant, and equipment decreases, the diminishing balance method should be used.

As far as the units of production method is concerned, it is necessary to consider replacing it with another method, in particular in order to eliminate tax differences.

4. Applying the recommended approach to selecting the depreciation method for property, plant, and equipment in oil and gas companies will improve the qualitative characteristics of financial statements in terms of the reliability of information about property, plant, and equipment.

The prospects for further research on the optimal selection of the depreciation method in oil and gas companies are seen in the development with the help of the automated accounting system of testing procedures for property, plant, and equipment within different groups in terms of the anticipated revenues, nature of assets use, and other factors (in particular, those affecting the useful life, residual value, if any). Firstly, this will be the basis for selecting the depreciation method and reduce the impact of subjectivity of thought. Secondly, the developed testing system will be used to further review the use of the depreciation method.

\section{REFERENCES}

[1] Financial Statements. Naftogaz Group. [Online]. Available: http://www.naftogaz.com/www/3/nakweb.nsf/0/c4775d2495121a4ac2 257ad90051f66d [in Ukrainian]

[2] I. M. Sacer, S. S. Malis, and I. Pavic, "The Impact of Accounting Estimates on Financial Position and Business Performance - Case of Non-Current Intangible and Tangible Assets", Procedia - Economics and Finance, Vol. 39, pp. 399-411, 2016. [Online]. Available: http://www.sciencedirect.com/science/article/pii/S2212567116303410 DOI: https://doi.org/10.1016/S2212-5671(16)30341-0. [in Ukrainian]

[3] G. Njowa, and C. Musingwini, “A framework for interfacing mineral asset valuation and financial reporting", Resources Policy, Volume 56, pp. 3-15, 2018. [Online]. Available: http://www.sciencedirect.com/science/article/pii/S0301420717302623 DOI: https://doi.org/10.1016/j.resourpol.2017.09.004. [in Ukrainian]

[4] M. P. Bauman, "The adequacy of fixed asset disclosures under U.S. GAAP", Research in Accounting Regulation, Volume 25, Issue 2, $\begin{array}{llll}\text { pp. 149-156, } 2013 . & \text { [Online]. Available: }\end{array}$ http://www.sciencedirect.com/science/article/pii/S1052045713000155 DOI: https://doi.org/10.1016/j.racreg.2013.08.002 [in Ukrainian]

[5] Z. Zadorozhnii, and S. Kafka, "Depreciation of non-current assets: harmonization of international practices and regulatory in Ukraine", Journal of Advanced Research in Management, Vol. VII, No. 1 (13), pp. 48-55, 2016. [Online]. Available: https://journals.aserspublishing.eu/jarm/issue/view/87 [in Ukrainian]

[6] M. I. Bondar, "Depreciation of non-current assets: accounting and taxation", The Journal of Zhytomyr State Technological University. Series: Economics, No. 1 (55), pp. 33-34, 2011. [in Ukrainian]

[7] S. A. Kuznetsova, and A. A. Kuznetsov, "Transformation of methodology and organization of accounting and management control for long-term tangible assets in conditions of information asymmetry and virtualization", Efficient economy, No. 8, 2018. [Online]. Available: http://www.economy.nayka.com.ua/pdf/8_2018/7.pdf [in Ukrainian]

[8] Z.-M. V. Zadorozhnii, L. H. Semehen, and L. T. Bohutska, Topical issues of the accounting policy of enterprises on non-current assets. Ternopil, Ukraine: TNEU, 2012. [in Ukrainian]

[9] Law of Ukraine "On Accounting and Financial Reporting in Ukraine" of July 16, 1999 № 996-XI. [Online]. Available: http://search.ligazakon.ua [in Ukrainian]

[10] Joint Stock Company "Ukrgasvydobuvannya". Financial Statement and Independent Auditor's Report for 2018. [Online]. Available: http://ugv.com.ua/uploads/Financial_Report_2018.pdf.17917928.609 5efcd30470af02046b97b5f28d62d.pdf [in Ukrainian]

[11] Financial results. Regular information of PJSC "Ukrnafta" [Online]. Available: https://www.ukrnafta.com/finansovi-rezultati. [in Ukrainian]

[12] JSC “Ukrtransgaz". Financial Statement and Independent Auditor's Report of December 31, 2018 and for the year ended on this date. [Online]. Available: http://utg.ua/img/menu/company/reports/2018/ audit-report-UTG-2018.pdf [in Ukrainian]

[13] Naftogaz. Ukrtransnafta. Documents. [Online]. Available: https://www.ukrtransnafta.com/dokumenti/ [in Ukrainian]

[14] Public Joint Stock Company "Transnational Financial and Industrial Oil Company "Ukrtatnafta". Annual Information of Securities Issuer for 2017. [Online]. Available: https://pep.org.ua/media/documents/ business-registry_company__Ukrtatnafta_Kolomoisky_2019.2.pdf [in Ukrainian]

[15] Public Joint Stock Company "On Provision of Gas Supply "Donetskoblgaz". Annual Information of Securities Issuer for 2018. [Online]. Available: http://oblgaz.donetsk.ua/files/ repdoc/report_2018.pdf [in Ukrainian]

[16] Regional Gas Company PJSC "Kyivoblgaz". Reports. [Online]. Available: https://kv.104.ua/ru/informacija-pro-kompaniju/ informacija-dlja-akcioneriv/accouting [in Ukrainian]

[17] International Accounting Standard 16 "Property, Plant, and Equipment". [Online]. Available: https://www.pkf. com/media/10033170/ias-16-property-plant-and-equipmentsummary.pdf [in Ukrainian]

[18] Accounting Standard 7 "Property, Plant, and Equipment". [Online]. Available: https://zakon0.rada.gov.ua/laws/show/z0288-00 [in Ukrainian]. 